\title{
READERS
Insight
}

Journal of Management Info (JMI)

ISSN:2313-3376

www.readersinsight.net/jmi

$\overline{M A}$

\section{Job rotation, job performance, organizational commitment: An empirical study on bank employees}

\author{
Faisal Khan ${ }^{1}$, Amran MD Rasli², Tariq ${ }^{3}$, Abid-ur-Rahman ${ }^{4}$, Muhammad Muddassar Khan ${ }^{5}$ \\ ${ }^{1,2,5}$ Faculty of Management (FM), Universiti Teknologi Malaysia (UTM), Skudai Johor, Malaysia \\ ${ }^{3}$ Faculty of Education, UTM, Skudai, Johor, Malaysia \\ ${ }^{3}$ Department of English, University of Malakand (UOM), Chakdara, Dir (L) \\ ${ }^{4}$ Abduli Wali Khan University Mardan \\ * Corresponding author: amrasli@gmwil.com
}

\begin{abstract}
The aim of the study is to investigate the relationship and effect of variables like job rotation, job performance and organizational commitment among the employees working in banking sector in Pakistan. Self-administrated questionnaire was distributed by selecting a convenient sampling. The data was collected from 435 employees in the banks. The data were analyzed with the help of Statistical Package of Social Sciences (SPSS). The findings of the study revealed that a positive relationship was found between job rotation, job performance and organizational commitment among the employees, whereas negative relationship was found between job performance and organizational commitment. The study results are useful for the bankers, employees' and managers. The study also provided the limitations and recommendations for future research.
\end{abstract}

\section{ARTICLE INFORMATION}

\author{
Received: 25 March 2014 \\ Revised: $\quad 25$ July 2014 \\ Accepted: 25 August 2014
}

DOI:

http://dx.doi.org//10.31580/jmi.v3i1.8

\section{Introduction}

In the present commercial world, the most essential and economically significant businesses are banking. The financial structure of a country depends on its economy. The most important strategies of job rotation for financial institutions in the $21^{\text {st }}$ century must be the practicing of effective and well designed, to commit, motivate and improve the performance of the people. In other words, job rotation is a mechanism through which the managers determines the employees' committement, productivity and innovation in their respective jobs (Ortega, 2001), also update them about the recent changes in professional climate, which criticize any organizations in order to survive and compete in today's market driven system effectively.

Job rotation is one of the factors to enhance the productivity of an organization, but it needs proper training and cooperative colleagues to support the employees in the current position (Gómez, Lorente, \& Cabrera, 2004). Job rotation is defined as the organized movement of an employee from one position to another position at a designed period in the same department (Malinski, 2002; Storey, 2001). It engages occasional shifting of employees from an assigned work to another where every work needs different experiences rules, obligations and expertise (Langton, Robbins, \& Judge, 2012). Similarly, Hiltrop et al., (1995) expressed that job rotation as a shifting of employees in different projects and positions, which is related to the previous environment. Furthermore, banks also concentrate on the same practices in their working environment and the managers decide it on the basis of their employees performance. Other factors relevant to the job rotation were also indicated in the studies that are, rotating homework, shifts and changes in the working environment, creativity, cross working exercise and re-posting. Job rotation has been defined as an organized move of employees from one job duty to another at a designed time and distance (Malinski, 2002). Job rotation is said to be a brilliant approach for the organizations to train their employees (Beatty, Schneier, \& McEvoy, 1987).

Moerover, organizational commitment is also one of the essential parts of an organization in this world (Allen \& Meyer, 1990). According to Meyer et al., (2002) organizational commitment is defined as to believe the values and aims of the organization, loyalty with organization, obligations and having sense to remain with the organization. Allen and Meyer (1984) also introduce that organizational commitment as a multiple component model. In addition, the Allen and Meyer (1984) model consists of three main components called affective, normative and continuous commitment. Employees play an important role in the advancement and quality enhancement of an organization (Spencer, 1994). Therefore, it is needed to develop the skill, knowledge, interests and understanding of the technological changes in the banking sectors. In similar fashion, the employees will work at different positions and places in banks, and at the time of categorizion, it will be based on their individual skill, knowledge and capability (Gómez et al., 2004). Recently, the bankers are apprehensive about the financial institutions, whereas they not only appeal to the employees for improving their commitment, but also rotates in order to get the fruitful outcome from them, which is becoming a sources of tough, complex and sometime unclear in a co-operated environment (Smith, 1995). With regard to recent changes in the banking sectors, Performance is also an important task within an organization (Boje, 1991; Oxenburgh, Marlow, \& Oxenburgh, 2004). Therefore, to enhance the productivity of an organization, it needs to develop enthusiasm, assurance and job attachment of an employee and to grant them valuable guidance plan. 
From all the aforementhioned discussion, it has been examined that loyal and interested employees are rendering better performance and efficiency for the organization (Madani \& Zahedi, 2005). Therefore, the researchers observed that there are many challenges (promotion, recruitment, performance, skill, knowledge) and difficulties in the working environment, but difificulties in the banking sector are tremendous. In addition, the current study tries to learn the understanding directed towards job rotation programs which stimulate the employees, operating for banks in Pakistan. It is also helpful for the banks to develop assurance, performance and job commitment of their employees. The current study also aims to inform managers about the rotation, performance and commitment of an employee towards his work in the banking sectors. For the last two decades, Government of Pakistan (GOP) has been continuinously struggling to plan the best performance rewarding different techniques and tools. Pakistan is considered as one of the largest contributors regarding the growth of GDP (F. Allen, Qian, \& Qian, 2005). Therefore, the GOP assumes to improve the productivity of employees throughout the financial institutions, while the GOP of Pakistan needs to examine the improvements in the banking sector. In the present world, the banking sector is on the linchpin of any country in both making money and growth. The current study focuses on the rotation regarding performance and commitment of an employee during the job in the same department, while the effects of performance on the organizational commitment. The current study was conducted in banking sector of Pakistan especially in Peshawar Khyber Pakhtunkhwa (KPK) Pakistan.

\section{Literature review}

Job Rotation has been used to implement the increasing employee momentum and taking active part in job within the organization, which are incredibly vital for valuable performance (Zeira, 1974). Job Rotation establishes a successful routine of increasing talents, enthusiasm, encouragement and motivation of an employee within the organization (Friedrich, Kabst, Weber, \& Rodehuth, 1998). Job Rotation is the procedure all the way through which an organization's employee learns work skill from different activities to eliminate burnout from the job tasks (Olorunsola, 2000). Job Rotation is an opening chance for worker to expand an admiration of organizational objectives, to produce more liberal facts of the dissimilar field, to build up a strong network of the organizational associates and to increment employee acquisitions (Lindbeck \& Snower, 2000).

Job Rotation is a system which is capable of augmenting employees' motivation and commitment within an organization and make wider observations as well. It brings an enlargement in work rate of human resources, tries to get better firm execution, individual mortal levels of multi-experienced employees, well obtainable capabilities and as well as new perspectives for attitude, deliberation, potentialities and hidden talent of employees (Cascio \& McEvoy, 1992). Job Rotation has been measured on practical techniques, particularly on the enhancement and growth of jobs. According to Delpasand et al., (2011) job rotation is defined as falls into the greater as compared to before individual knowledge, familiarity and tiredness, which leads to rational expansion and improvement of an individual capabilities.

Job rotation has much significance in commercial environment in the world. It is used by the stakeholders within the organizations to extend workers, managers and executives (Beatty et al., 1987). Job rotation is used to elastic work strength and standing by supply of skilled human resources to provide as a ready for action frame for the organizations (Rothwell \& Kazanas, 2004). It advances the employee's abilities and mutual understanding of their job. It increases team effectiveness and facilitate the employees to reward promotion chances after successful achievement of work rotation programs (Faegri, Dybå, \& Dingsøyr, 2010). Therefore, it has been concluded that both the human resources and owners can get profit from job rotation practices. Organizational researchers claim that job rotation is one of the strongest predictors of performance and commitment during the job. It reduces the boredom and fatigue of the jobs and enhances the employee motivation and commitment through diversification of the tasks, which is highly recommended, for the innovative organizations to develop the workforce in order to meet the current and future requirements of the dynamic fruitful environment (Adomi, 2006).

Today's specialized type of business nature requires the financial associations and institutions, including banks, to bring in ingenious job rotation programs which tolerate the employees to be trained in order to find their feet at new skills help them to keep themselves upto-date. Therefore, job rotation is said to be an excellent tool for enhancing employee commitment and job performance, which is very important for the smooth and effective functioning of an organization (Schein, 1967, 2003; Zeira, 1974). However, in the existing literature less attention has been given to relationship between job rotation, commitment and performance, therefore the current study was conducted on the relationship between impact of job rotation on employee performance and commitment.

This research informs manager's observations about the value of job rotational practices and its input for the employee obligation, motivation and job contribution. This workout is prearranged as follows; a summary of the related literature; tactic of the study; examination of facts composed; end of the study consists of discussion about the findings and put forward suggestions.

Organizational commitment is one of the most important factors in the organizational performance. Organizational commitment is defined as the sense of an individual which depends on the organization. According to Modways et al., (1984) Organizational commitment is an effective matter, whereas it defines the employees having strong interest and attachment to the organization. Commitment to the organization employees have, are of three types. First, belief acceptance of the rule and regulations of an organization, second, realizing the goals and third, stay with the organization. While Meyer et al., (2002) defines organizational commitment is a multi component model. It is mostly defined as the combination of three components called affective, continuous and normative commitment of the employees. Affective commitment is the adherence of an employee's towards organizations, continuous refers to cost and benefits related to remain or leave the organization while normative commitment is related to the obligation of an employee within the organization (Allen \& Meyer, 1990).

Performance is considered as a behavior and can be operated in different techniques such as individual performance, the group's performance and organizational performance. The performance of the employees can be determined both positive and negative (Jans \& Frazer-Jans, 2004). According to the Panatik (2012) studies examine that job stress affects the organizational commitment, job performance, job satisfaction, turnover intentions and overall productivity of an employee. Consequently, some unwanted physical and psychological problems were developed by job stress among employees in their working environment, whose outcome is not so good and have poor performance and less commitment to their organization.

In additions, financial institutions like banks has declared economic development, thus the environment of job in banks has become complex, and the employees can not complete their tasks as assigned to them, whereas it not only affects the performance of the employees but also affect the organizational performance. The employees also require to bring the investor to invest in the sector for the development and circulation of economy, which shows the productivity and profitability of the human resources. Furthermore, high organizational performance depends on the organizational capabilities of an employee in their working environment (Noe, Hollenbeck, Gerhart, \& Wright, 2004). To examine the performance of an employee, job rotation is also used for the operating system in the sector to enhance the productivity of human capital to improve the organizational performance and individual performance. Due to enhancement in productivity of an employee, it improves the commitment and the satisfaction level of the employee within the organization. They also claim that it saves time and resources to facilitate the customers (Origo \& Pagani, 2008). Job rotation is also 
defined as the systematic replacement of the employees to train the perfect human resources in competitive advantage.

\section{Methodology}

In the current study, survey technique was used for the descriptive study by using the SPSS (version 18.0). A self-administrated questionnaire was used for data collection. In the current study, a reliable scale for the variable job rotation, performance and organizational commitment was used with five Likert scale ranging from 1 to 5 (Strongly Disagree to Strongly Agree). The questionnaire consists of four main sections, first section consists of demographic or personal characteristics like age, marital status, gender and experience, second consists of questions related to job rotation. Third sections of questions related to job performance and the last section of the questionnaire consist of organizational commitment items. Organizational commitment was analyzed by 18 factors of Allen and Meyer (1990), while six items analyzed job rotation and having reliability of 0.81 . In the current study the researcher used the convenient sampling and selected Peshawar division which is the largest division in KPK (KPK, 2013). Peshawar is the capital of KPK, having every branch of banks. The researcher visited different banks branch and distributed the questionnaires among the all employees. 534 questionnaires were distributed. The researcher himself distributed every questionnaires to employees, some of them refused to fill in the questionnaire, a total 463 were collected where 28 were useless and incomplete, which were not suitable for using final data analysis. The response rate of the selected bank employees in KPK Peshawar division was $87 \%$, which is a very good response to the data analysis.

In the current study, the descriptive statistics are used; therefore, it not only examines the characteristics of the respondents, but also informs the researchers and bankers for the prevalence of the study variables in the bank sector especially in KPK Pakistan. To examine the relationship between the variables correlation has been used, while for the effect of the variable the regression analysis has been carried out. Therefore, the current study has established the following hypotheses, to be tested in the current study as follows:

H1: Job rotation has a significant relationship with organizational commitment among the employees in the banking sector.

H2: Job rotation has a significant relationship with Job performance among the employees in the banking sector.

H3: Job performance has a significant relationship with organizational commitment among the employees in the banking sector.

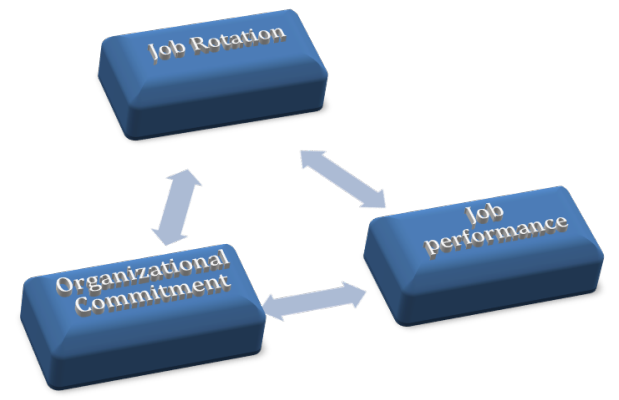

Fig. 1. Framework Model of the study

\section{Results and discussion}

In the findings of the current study, Table 1 provides the personal or demographic characteristics of the respondents from banking sectors. The response characteristics consist of gender, age and experience. According to the table results a total 435 questionnaires were used for the final data analysis of the current study. In which, the male respondents were more than female because in Pakistan females have more problems in performing their jobs in every sector, which was also proved as an evidence by the study. Therefore, the male ratio in the current study on banking sector is 54.5 percent. In addition, the table also provided that, the younger employees working in the banking sector are also more as compare to the higher experiences. Furthermore, the Table also explains that most of the employees were in the age of between 30 and 35, which shows that the employees in these ages were establishing their families and thus having a lot of stress and burnout from their professions and want to improve their professional development (Khan, Rasli, Khan, Yasir, \& Malik, 2014).

\begin{tabular}{|c|c|c|}
\hline Characteristics & Respondents (n) & \%age \\
\hline \multicolumn{3}{|l|}{ Gender } \\
\hline Male & 237 & 54.5 \\
\hline Female & 208 & 47.8 \\
\hline \multicolumn{3}{|l|}{ Experience } \\
\hline Less than 3 years & 173 & 39.8 \\
\hline From 4 to 7 & 132 & 30.34 \\
\hline From 8 to 10 & 81 & 18.6 \\
\hline More than 10 & 49 & 11.3 \\
\hline \multicolumn{3}{|l|}{ Age } \\
\hline Above 35 & 33 & 7.5 \\
\hline $30-35$ & 155 & 35.6 \\
\hline $26-30$ & 116 & 26.7 \\
\hline Less than 25 & 131 & 30.1 \\
\hline
\end{tabular}

Furthermore, the study will also examine the relationship and effects of the study variables. Therefore, Table 2 provides the detailed statistical analysis of the current study variables. The job rotation variable has a mean value of 2.97 with a higher standard deviation of 0.72, indicating the thinking of respondents, where there is a moderate level of rotation in banking sectors. On the other hand, the larger standard deviation illustrated that there is a difference of opinion among the employees in the banking sectors regarding the organizational commitment and job performance. Similarly, the mean of job performance is 3.88 and the standard deviation is 0.64 , while the organizational commitment is 0.67 and 4.01 as shown in the Table 2. In addition, the current study also states that they are more interrelated, significant, and positive with each other. The results of the current study is parallel with the previous study, whereas the study is illustrated that high level of job performance have a high level of job rotation (Campion, Cheraskin, \& Stevens, 1994). In like manner, the finding of the current study also suggestes that a negative relationship was found between job performance and organizational commitment. therefore the results of the study is parallel to the results of the studies like Wright, (1997), Mathieu and Zajac (1990) and Mowday et al., (1982).

\section{Conclusion and recommendation for future research}

The current study was carried out to show the importance of job rotation, job performance and organizational commitment in banking sectors. From the results of the study, it is clear that as the rotation within the working environment is increasing, the employees' commitment to the organization is also increasing, which in turn increases the loyalty of the employees within the organization (M. Zigarelli, 2008; M. A. Zigarelli, 2002). On the other hand, job rotation increases the motivation level of the employee therefore the performance is also increased.

The study has some limitation. First, the researcher has financial problems, therefore the researcher collected one time targeted data, which is called cross-sectional approach and recommends that in future the studies should be done as a longitudinal approach. The sample of the current study was from one division of KPK Pakistan so the researcher recommends that in future it could also be tested in comparison to other provinces of Pakistan. The study used the convenient sampling while for future research the researcher recommends the use of a large sample size for more accurate results. 
Table 2: Mean, Standard Deviation, Reliability Analysis, Correlation Matrix

\begin{tabular}{|c|c|c|c|c|c|c|c|c|}
\hline Variables & Cronbach's Alpha & 1 & 2 & 3 & Mean & S.D & Min & Max \\
\hline Job Rotation & 0.81 & 1 & & & 2.97 & 0.72 & 2.9 & 3.0 \\
\hline Job Performance & 0.72 & 0.690 & 1 & & 3.88 & 0.64 & 2.4 & 4.1 \\
\hline Organizational Commitment & 0.77 & 0.701 & -0.641 & 1 & 4.01 & 0.67 & 2.5 & 2.3 \\
\hline
\end{tabular}

\section{References}

Adomi, E. E. (2006). Job rotation in Nigerian university libraries. Library Review, 55(1), 66-74

Allen, \& Meyer. (1990). The measurement and antecedents of affective, continuance and normative commitment to the organization. Journal of Occupational Psychology, 63(1), 1-18. doi: 10.1111/j.20448325.1990.tb00506.x

Allen, F., Qian, J., \& Qian, M. (2005). Law, finance, and economic growth in China. Journal of financial economics, 77(1), 57-116.

Beatty, R. W., Schneier, C. E., \& McEvoy, G. M. (1987). Executive development and management succession. Research in personnel and human resources management, 5, 289-322.

Boje, D. M. (1991). The storytelling organization: A study of story performance in an office-supply firm. Administrative Science Quarterly, 106-126.

Campion, M. A., Cheraskin, L., \& Stevens, M. J. (1994). Career-related antecedents and outcomes of job rotation. Academy of Management Journal, 37(6), 1518-1542.

Cascio, W. F., \& McEvoy, G. (1992). Managing human resources: Productivity, quality of work life, profits (Vol. 2): McGraw-Hill.

Delpasand, M., Nasiripoor, A. A., Raiisi, P., \& Shahabi, M. (2011). Relationship between emotional intelligence and occupational burnout among nurses in Critical Care Units. Iranian Journal of Critical Care Nursing, 4(2), 79-86.

Faegri, T. E., Dybå, T., \& Dingsøyr, T. (2010). Introducing knowledge redundancy practice in software development: Experiences with job rotation in support work. Information and Software Technology, 52(10), 1118-1132.

Friedrich, A., Kabst, R., Weber, W., \& Rodehuth, M. (1998). Functional flexibility: merely reacting or acting strategically? Employee Relations, 20(5), 504-523.

Gómez, P. J., Lorente, J. J. C., \& Cabrera, R. V. (2004). Training practices and organisational learning capability: Relationship and implications. Journal of European Industrial Training, 28(2/3/4), 234-256.

Hiltrop, J.-M., Despres, C., \& Sparrow, P. (1995). The changing role of HR managers in Europe. European Management Journal, 13(1), 91-98.

Jans, N., \& Frazer-Jans, J. (2004). Career development, job rotation, and professional performance. Armed Forces \& Society, 30(2), 255-277.

Khan, F., Rasli, A. M., Khan, S., Yasir, M., \& Malik, M. F. (2014). Job burnout and Professional Development Among Universities Academicians. Science International Lahore, 26(4).

KPK. (2013). Khyber Pakhtunkhwa (NWFP) - the land of Pakhtoons. Retrieved 1st Nov, 2013, from http://www.pakpakistan.org/khyberpakhtunkhwa-nwfp-the-land-of-pakhtoons/

Langton, N., Robbins, S. P., \& Judge, T. A. (2012). Organizational behaviour: Concepts, controversies, applications: Pearson Education Canada.

Lindbeck, A., \& Snower, D. J. (2000). The division of labor and the market for organizations: CESifo Working papers.

Madani, H., \& Zahedi, M. (2005). Determining the Priority of the Affecting Factors In the Organizational Commitment of Employees in Fajr and Bidboland Gas Companies. IRANIAN JOURNAL OF SOCIOLOGY (ISA), $6(1), 3-3$.
Malinski, R. M. (2002). Job rotation in an academic library: Damned if you do and damned if you don't! Library Trends, 50(4), 673-680.

Mathieu, J. E., \& Zajac, D. M. (1990). A review and meta-analysis of the antecedents, correlates, and consequences of organizational commitment. Psychological Bulletin, 108(2), 171-194.

Meyer, J. P., \& Allen, N. J. (1984). Testing the" side-bet theory" of organizational commitment: Some methodological considerations. Journal of Applied Psychology, 69(3), 372.

Meyer, J. P., Stanley, D. J., Herscovitch, L., \& Topolnytsky, L. (2002). Affective, Continuance, and Normative Commitment to the Organization: A Meta-analysis of Antecedents, Correlates, and Consequences. Journal of Vocational Behavior, 61(1), 20-52. doi: http://dx.doi.org/10.1006/jvbe.2001.1842

Mowday, R. T., Koberg, C. S., \& McArthur, A. W. (1984). The Psychology of the Withdrawal Process: A Cross-Validational Test of Mobley's Intermediate Linkages Model of Turnover in Two Samples. The Academy of Management Journal, 27(1), 79-94. doi: 10.2307/255958

Mowday, R. T., Porter, L. W., \& Steers, R. M. (1982). Employee organization linkages: New York: Academic Press.

Noe, R. A., Hollenbeck, J. R., Gerhart, B., \& Wright, P. M. (2004). Fundamentals of human resource management (Vol. 2): McGraw-Hill.

Olorunsola, R. (2000). Job rotation in academic libraries: the situation in a Nigerian university library. Library management, 21(2), 94-98.

Origo, F., \& Pagani, L. (2008). Workplace flexibility and job satisfaction: some evidence from Europe. International Journal of Manpower, 29(6), 539-566.

Ortega, J. (2001). Job rotation as a learning mechanism. Management science, 47(10), 1361-1370.

Oxenburgh, M., Marlow, P. S., \& Oxenburgh, A. (2004). Increasing productivity and profit through health and safety: the financial returns from a safe working environment: CRC Press.

Panatik, S. A. (2012). The relationship between psychosocial stressors and work attitudes: the mediating effects of psychological strain. International Journal of Social Sciences and Humanity Studies, 4(2), 451-460.

Rothwell, W. J., \& Kazanas, H. C. (2004). Improving on-the-job training: How to establish and operate a comprehensive OJT program: John Wiley \& Sons.

Schein, E. H. (1967). Organizational socialization and the profession of management. Sloan Management Review, 30.

Schein, E. H. (2003). Organizational socialization and the profession of management. Organizational influence processes, 283-294.

Smith, B. (1995). Process reengineering: the toughest challenge. HR Focus. $72(2), 24$

Spencer, B. A. (1994). Models of organization and total quality management: a comparison and critical evaluation. Academy of Management Review, $19(3), 446-471$

Storey, J. (2001). Human resource management: A critical text: Thomson.

Wright, T. A. (1997). Job performance and organizational commitment. Perceptual and Motor Skills, 85(2), 447-450.

Zeira, Y. (1974). Job rotation for management development. Personnel, 51(4), 25-35.

Zigarelli, M. (2008). Management by Proverbs: Xulon Press.

Zigarelli, M. A. (2002). Ordinary People, Extraordinary Leaders: Synergy Publishers (FL). 